\title{
Spectrophotometric Determination of Niclosamide by Prior Reduction and Subsequent Diazotization-Coupling with 2,6-Dihydroxybenzoic acid - Application to Tablets
}

\author{
Nabeel S. Othman \\ Saad H. Sultan \\ Department of Chemistery \\ College of Science \\ University of Mosul
}

(Received 2/1/2013;Accepted 18/3/2013)

\begin{abstract}
A simple, rapid and sensitive spectrophotometric method is proposed for the determination of niclosamide (NIC) in pure form and in its pharmaceutical preparations. The method is based on the reduction of niclosamide by zinc powder in acidic medium followed by the diazotization of reduced niclosamide, then coupling with 2,6dihydroxybenzoic acid to give a yellow colored product which is water - soluble and has a maximum absorption at $456 \mathrm{~nm}$ with a molar absorptivity of $2.36 \times 10^{4} 1 . \mathrm{mol}^{-1} . \mathrm{cm}^{-1}$. The color reaction is highly stable and does not show a significant change in absorbance up to 24 hours. Beerś law is obeyed in the concentration range of 5-300 $\mu \mathrm{g}$ of niclosamide in a final volume of $10 \mathrm{ml}$. The method has been successfully applied to the determination of niclosamide in tablets.
\end{abstract}

Keywords: Niclosamide, reduction, diazotization and coupling, 2,6-dihydroxybenzoic acid coupling agent, spectrophotometry.

القير الالي لانيكلوساميد بالختزل المسق.متبوعا" بالزوتة والفترل مع الكلثف 6،2- شائي هيدوكسي حامض البنزوك - التلبق عل الفرله الدوائية

\section{الملغص}

قم اقتراح طريقة طيفية بسيطة وسريعة ومسلسة لقدير النيكلوسلميد بشكله القي وفي مستحضراته

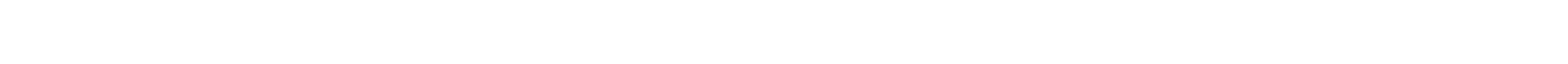

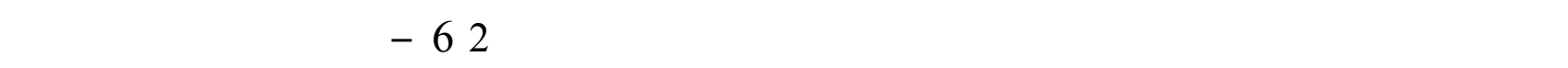

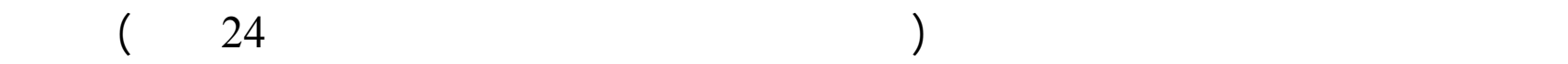
في المحلول المائي وله أعلى لمتصاص عند الطول ألموجي 456 نانوميتر وقد كالنت قيمة المتصاصية

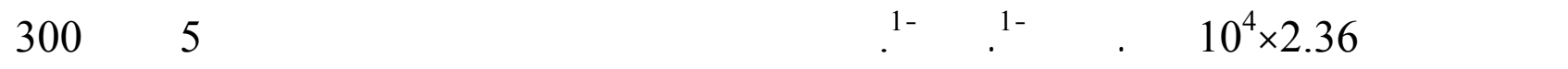


مايكروغرلم من النيكلوسلميد في حهم نهائي 10 مللتر، وقد مه ظبيق الطريقة المقترحة بنجاح لقدير النيكلوسلميد في الأقراص الدوائية.

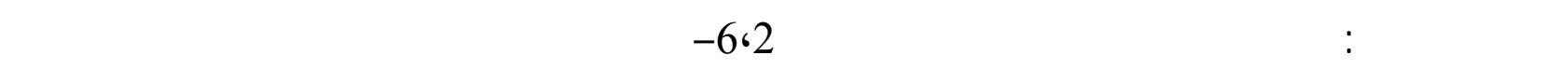
اقتران،طريقةطيفية.

\section{INTRODUCTION}

Niclosamide (NIC) is one of the anthelmintics of first choice in the treatment of beef tapeworm Taenia saginata, fish tapeworm Diphyllobothrium latum and pork tapeworm Taenia solium; an alternate drug of choice for dwarf tapeworm Hymenolepis nana infections. It inhibits phosphorylation in the mitochondria of cestodes. NIC and its two novel synthesized derivatives constructed to float on the water surface were able to kill cercariae (Wu et al., 2011; Sheng et al., 2011), also possessed promising activity in vitro against an apicomplexan parasite Toxoplasma gondii (Fomovska et al., 2012). Untoward effects occur only occasionally; nausea and abdorminal pain have been reported most frequently (Alfonso,1995). Niclosamide has different propriety names such as: Cestocide; Niclocide; Ruby; Yomesan (Budavari, 2001). Niclosamide is chemically named as 5chloro- $\mathrm{N}-(2-$ chloro-4-nitrophenyl)-2- hydroxybenzamide and has the following chemical structure:<smiles>O=C(Nc1ccc([N+](=O)[O-])cc1Cl)c1cc(Cl)ccc1O</smiles>

$$
\text { M.Wt. }=327.1 \mathrm{~g} / \mathrm{mol}
$$

\section{Niclosamide $\left(\mathrm{C}_{13} \mathrm{H}_{8} \mathrm{Cl}_{2} \mathrm{~N}_{2} \mathrm{O}_{4}\right)$}

NIC is a yellowish - white or yellowish, fine crystals, practically insoluble in water, slightly soluble in ethanol (British Pharmacopeia, 2000).

Few spectrophotometric methods have been reported for the determination of niclosamide in pure form or in formulations depend on the reduction of nitro group with zinc powder in acidic medium followed by reaction with different reagents such as metol and potassium dichromate at $\mathrm{pH} 3.0$ to give a colored product having maximum absorbance at $530 \mathrm{~nm}$ (Sastry et al.,1988), p-benzoquinone to form a pink product which absorbs at $506 \mathrm{~nm}$ (Abdel Fattah, 1997), and with phloroglucinol after diazotization (Al-Allaf, 2010). The derivative spectrophotometric methods have been used in simultaneous determination of niclosamide in presence of drotaverine hydrochloride (Daabees, 2000) or thiabenazole (Onur and Tekin, 1994) in the same formulations. Niclosamide is also determined in tablets by the dissolution of the tablets in sodium hydroxide solution $(0.1 \mathrm{M})$ followed by 
measurement of the absorbance at $375 \mathrm{~nm}$ (Lopatin et al., 1989). Also, the fluorescence derivatization method has been used in the determination of niclosamide (Algarra et al., 2012). The chromatographic methods for the determination of niclosamide include high performance liquid chromatography (Schreier, 2000; Cholifah, 2008), LC-MS (Caldow et al., 2009), and gas chromatography (Churchill and $\mathrm{Ku}, 1980$; John and Geuffery, 1980). The electrochemical methods for the determination of niclosamide based on square - wave voltammetry (Alemu et al., 2003), or by cyclic voltammetry at a glassy carbon electrode (Abreu et al., 2002), or modified electrode for electro-catalytic reduction of niclosamide (Ghalkain and Shahrokhian, 2010).

The aim of the current study is the description of a simple and accurate spectrophotometric determination of niclosamide. The method based on the reduction of nitro group in niclosamide then diazotization and coupling with 2,6 - dihydroxybenzoic acid to form a colored azo dye that has been proved successfully for the determination of niclosamide in both pure form and in its pharmaceutical preparations.

\section{Instruments}

\section{EXPERIMENTAL}

All spectrophotometric measurements are performed on Shimadzu UV-160A UVVisible recording spectrophotometer with $1.0 \mathrm{~cm}$ matched plastic cells.

\section{Reagents}

All chemicals used are of analytical- reagent grade.

Niclosamide solution, $10000 \mu \mathrm{g} \cdot \mathrm{ml}^{-1}$.

This solution is prepared by dissolving $0.5 \mathrm{~g}$ of pure niclosamide (Sigma, Italy) in 50 $\mathrm{ml}$ of $1: 1$ ethanol : acetone mixture in a volumetric flask.

\section{Reduced niclosamide(RNIC) solution, $500 \mu \mathrm{g} \cdot \mathrm{ml}^{-1}$.}

$5.0 \mathrm{ml}$ of $\mathrm{NIC}\left(10000 \mu \mathrm{g} \cdot \mathrm{ml}^{-1}\right)$ solution is transferred into calibrated flask, $0.1 \mathrm{~g}$ of zinc powder and $5 \mathrm{ml}$ of hydrochloric acid (1M) were then added, then the flask was allowed to stand for 15 minutes on boiling water-bath, cooled and the solution filtered into $100 \mathrm{ml}$ volumetric flask, then made up to the mark with distilled water (British Pharmacopia, 2000).

\section{Reduced working niclosamide solution, $100 \mu \mathrm{g} \cdot \mathrm{ml}^{-1}$.}

$20 \mathrm{ml}$ of $500 \mu \mathrm{g} . \mathrm{ml}^{-1}$ is diluted with distilled water to the mark in a $100 \mathrm{ml}$ volumetric flask.

\section{Hydrochloric acid solution, $1 \mathrm{M}$.}

This solution is prepared by diluting $8.6 \mathrm{ml}$ of the concentrated acid (Thomas Baker) to the mark with distilled water in a $100 \mathrm{ml}$ volumetric flask.

\section{Sodium nitrite solution, $1 \%$.}

This solution is prepared by dissolving $1.0 \mathrm{~g}$ of sodium nitrite $(\mathrm{BDH})$ in $100 \mathrm{ml}$ distilled water in a volumetric flask. 
Sulphamic acid solution, $3 \%$.

This solution is prepared by dissolving $3.0 \mathrm{~g}$ of sulphamic acid (BDH) in $100 \mathrm{ml}$ distilled water in a volumetric flask.

\section{2,6-Dihydroxybenzoic acid solution, $0.1 \%$.}

This solution is prepared by dissolving $0.1 \mathrm{~g}$ of 2,6- dihydroxybenzoic acid (Fluka) in $100 \mathrm{ml}$ distilled water .

\section{Sodium hydroxide solution, $1 \mathrm{M}$.}

This solution is prepared by the appropriate dilution of the concentrated volumetric $(\mathrm{BDH})$ solution with distilled water and then transferred to a plastic bottle.

Tablets (Yomesan) solution, $10000 \mu \mathrm{g} \cdot \mathrm{ml}^{-1}$.

Ten tablets of niclosamide (each tablet contains $500 \mathrm{mg}$ niclosamide) are finely powdered, an accurately weighed of the powder equivalent to $0.5 \mathrm{~g}$ is dissolved in $20 \mathrm{ml}$ of 1:1 ethanol - acetone mixture and the residue is filtered into $50 \mathrm{ml}$ calibrated flask and then the volume completed to mark by repeated washing with the same solvent.

\section{Reduced niclosamide (RNIC) and working solution.}

$5.0 \mathrm{ml}$ of tablet (Yomesan) solution $\left(10000 \mu \mathrm{g} . \mathrm{ml}^{-1}\right)$ is transferred into a calibrated flask, and treated in the same way as the standard to prepare the RNIC solution $\left(500 \mu \mathrm{g} . \mathrm{ml}^{-1}\right)$ and the working solution $\left(100 \mu \mathrm{g} . \mathrm{ml}^{-1}\right)$ was prepared as mentioned before.

\section{Procedure and calibration graph}

To a series of $10 \mathrm{ml}$ calibrated flasks, an increasing volume covering the concentration range $(5-400) \mu \mathrm{g}$ of niclosamide solution is transferred, followed by the addition of $0.3 \mathrm{ml}$ of $1 \mathrm{M}$ hydrochloric acid and $0.75 \mathrm{ml} 1 \%$ sodium nitrite solutions with occasional shaking for 2 min., a $0.5 \mathrm{ml}$ at 3\% sulphamic acid solution is then added, with occasional shaking and standing for $1 \mathrm{~min}$. to remove the excess of sodium nitrite, $2 \mathrm{ml}$ of $0.1 \% 2,6-$ dihydroxybenzoic acid reagent solution and then $0.6 \mathrm{ml}$ of $1 \mathrm{M} \mathrm{NaOH}$ are added. After dilution with distilled water to the mark, the absorbances are measured at $456 \mathrm{~nm}$ against the reagent blank. Beers law is obeyed over the range of concentration 5 to $300 \mu \mathrm{g}$ niclosamide in $10 \mathrm{ml}\left(0.5-30 \mu \mathrm{g} \cdot \mathrm{ml}^{-1}\right)$ (Fig. 1$)$. The apparent molar absorptivity referred to niclosamide has been found to be $2.36 \times 10^{4} 1 . \mathrm{mol}^{-1} \mathrm{~cm}^{-1}$. 


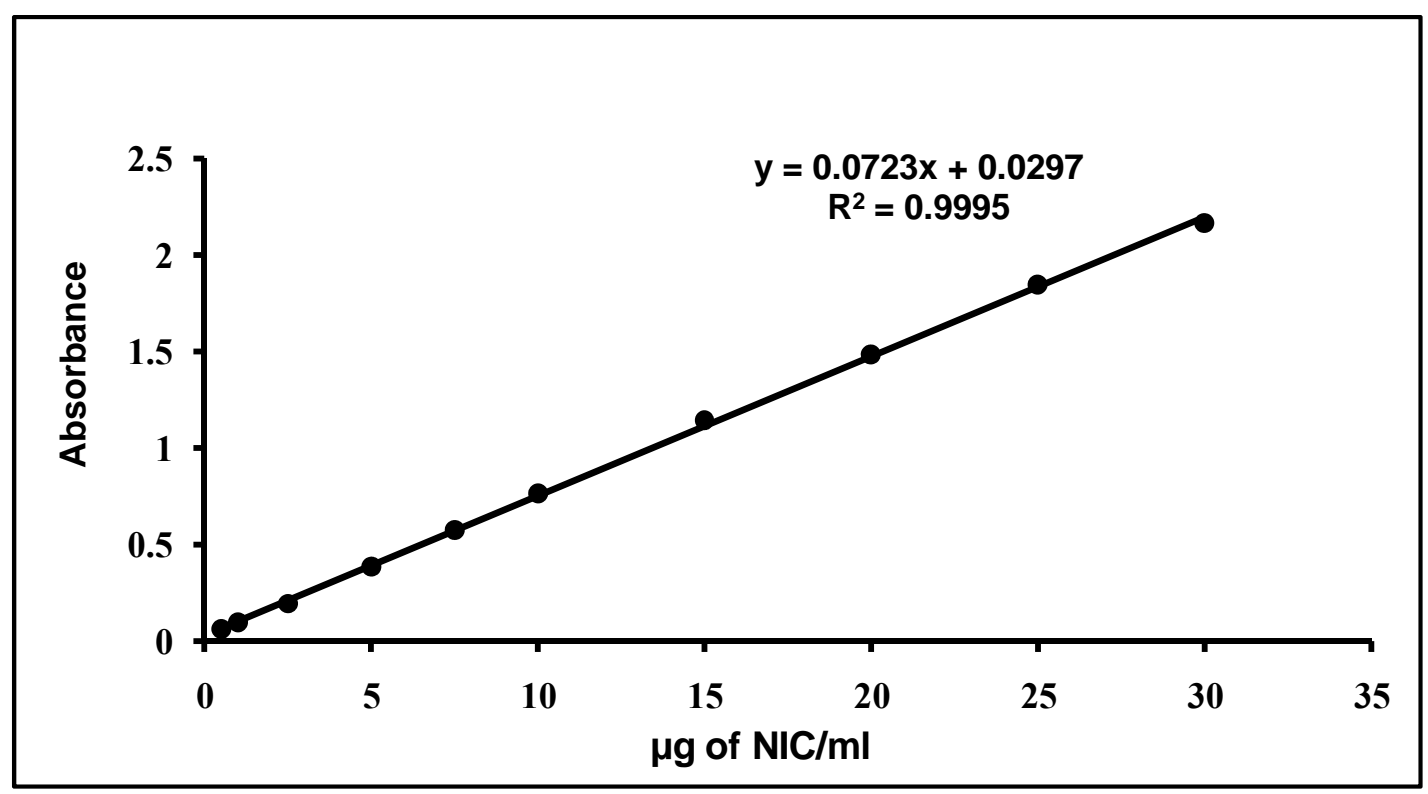

Fig. 1: Calibration graph for niclosamide determination using the proposed method

\section{RESULTS AND DISCUSSION}

During the investigation, $50 \mu \mathrm{g}$ of niclosamide is taken and the final volumes are brought to $10 \mathrm{ml}$ with distilled water.

\section{Principle of the method}

The first step for the determination, based on the reduction of the nitro group in niclosamide to the amino group by treatment with zinc powder and dilute $\mathrm{HCl}$ for $15 \mathrm{~min}$. in boiling water-bath as shown in the following reaction:

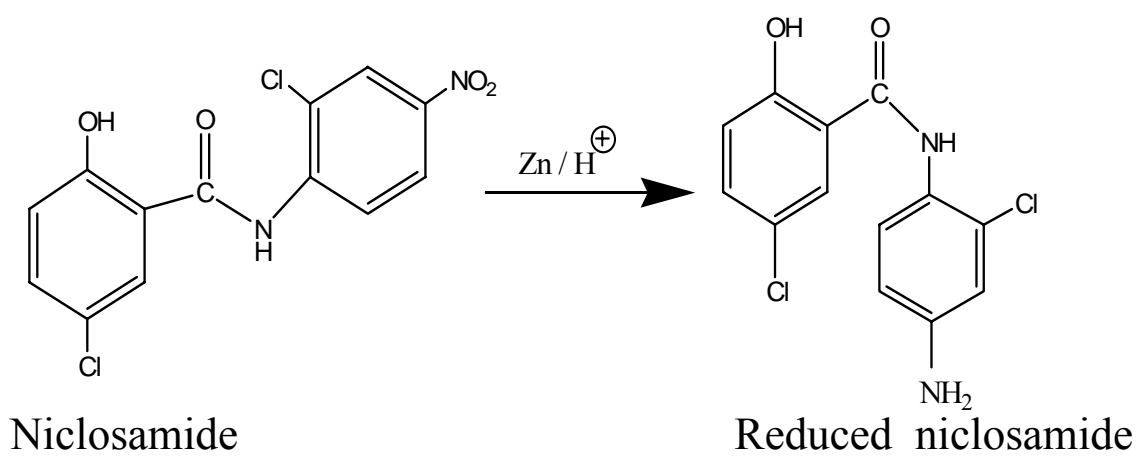

The produced amine is allowed to react in acidic medium with excess nitrite to form the corresponding diazonium salt which is then coupled in a basic medium with 2,6dihydroxybenzoic acid to form an intensely yellow colored azo dye: 
<smiles>Nc1ccc(NC(=O)c2cc(Cl)ccc2O)c(Cl)c1</smiles><smiles>N#[N+]c1ccc(NC(=O)c2cc(Cl)c(C=CC(=O)[O-])cc2O)c(Cl)c1</smiles><smiles>N#[N+]c1ccc(NC(=O)c2cc(Cl)ccc2O)c(Cl)c1</smiles><smiles>O=C(O)c1c(O)cccc1O</smiles>

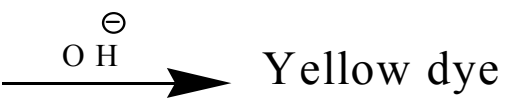

\section{Optimization of variables}

The effect of various parameters on the absorption intensity of the colored azo dye is studied and the reaction conditions have been optimized.

\section{Effect of acid used for diazotization reaction}

The effect of quality and quantity of acid on the intensity of the colored dye is examined. Different volumes of $1 \mathrm{M}$ of different acids are added to an aliquot of solution containing $50 \mu \mathrm{g}$ of reduced niclosamide (RNIC). The intensities of absorption are read against the reagent blank at $\lambda_{\max }=456 \mathrm{~nm}$. The results are shown in Table (1).

Table 1: Effect of quality and quantity of some used acids

\begin{tabular}{|l|c|c|c|c|c|c|}
\hline \multirow{2}{*}{$\begin{array}{c}\text { Acid used } \\
(\mathbf{1 M}) \text { solution }\end{array}$} & \multicolumn{6}{|c|}{ Absorbance / ml acid added } \\
\cline { 2 - 7 } & $\mathbf{0 . 1}$ & $\mathbf{0 . 2}$ & $\mathbf{0 . 3}$ & $\mathbf{0 . 4}$ & $\mathbf{0 . 5}$ & $\mathbf{1 . 0}$ \\
\hline $\mathbf{H C l}$ & 0.096 & 0.380 & 0.386 & 0.361 & 0.352 & 0.342 \\
\hline $\mathbf{H}_{\mathbf{2}} \mathbf{S O}_{4}$ & 0.083 & 0.324 & 0.346 & 0.329 & 0.339 & 0.323 \\
\hline $\mathbf{H N O}_{\mathbf{3}}$ & 0.072 & 0.360 & 0.357 & 0.359 & 0.341 & 0.321 \\
\hline $\mathbf{C H}_{\mathbf{3}} \mathbf{C O O H}$ & 0.101 & 0.355 & 0.358 & 0.360 & 0.360 & 0.302 \\
\hline
\end{tabular}

The results shown in Table 1 indicate that $0.3 \mathrm{ml}$ of $1 \mathrm{M} \mathrm{HCl}$ is considered as an optimum value, therefore it is recommended for subsequent experiments. 


\section{Effect of sodium nitrite amount and time}

Different amounts of $1.0 \% \mathrm{NaNO}_{2}$ solution are added and the time needed to complete diazotization of (RNIC) is studied by standing the solution after adding sodium nitrite solution for different times, with occasional shaking, then the other reagents are added and the absorbance is measured against the reagent blank. The results in Table (2) indicate that complete diazotization of RNIC occurs after 2 min. when $0.75 \mathrm{ml}$ of $1.0 \% \mathrm{NaNO}_{2}$ solution is added because it gives the higher sensitivity, therefore it has been selected for subsequent experiments.

Table 2: Effect of sodium nitrite and time

\begin{tabular}{|c|c|c|c|c|c|c|}
\hline \multirow{2}{*}{$\begin{array}{c}\text { ml of 1\% } \\
\text { NaNO } \\
\text { solution }\end{array}$} & \multicolumn{7}{|c|}{ Absorbance / standing time (min.) } \\
\cline { 2 - 7 } & $\mathbf{0}$ & $\mathbf{1}$ & $\mathbf{2}$ & $\mathbf{3}$ & $\mathbf{5}$ & $\mathbf{7}$ \\
\hline $\mathbf{0 . 2 5}$ & 0.377 & 0.372 & 0.372 & 0.373 & 0.366 & 0.360 \\
\hline $\mathbf{0 . 5}$ & 0.361 & 0.372 & 0.371 & 0.362 & 0.361 & 0.369 \\
\hline $\mathbf{0 . 7 5}$ & 0.362 & 0.375 & 0.385 & 0.360 & 0.372 & 0.361 \\
\hline $\mathbf{1 . 0}$ & 0.359 & 0.367 & 0.367 & 0.370 & 0.374 & 0.370 \\
\hline
\end{tabular}

\section{Effect of sulphamic acid amount with the time}

The effect of the amount of 3\% sulphamic acid solution for removing the excess sodium nitrite and the standing time with occasional shaking are investigated. The results in Table (3) indicate that complete reaction of sulphamic acid with sodium nitrite occurs after $1 \mathrm{~min}$. when $0.5 \mathrm{ml}$ of $3 \%$ sulphamic acid solution is added with corresponding low reagent blank absobance and the intensity decreased above $1 \mathrm{~min}$. Therefore, $0.5 \mathrm{ml}$ of $3 \%$ sulphamic acid solution with standing time $1 \mathrm{~min}$. is recommended for the subsequent experiments.

Table 3 : Effect of sulphamic acid amount with the time

\begin{tabular}{|c|c|c|c|c|c|c|c|}
\hline \multirow{2}{*}{$\begin{array}{c}\text { ml of } 3 \% \text { sulphamic } \\
\text { acid } \\
\text { solution }\end{array}$} & \multirow{2}{*}{ Variable } & \multicolumn{6}{|c|}{ Absorbance / standing time (min.) } \\
\hline & & $\mathbf{0}$ & 1 & 2 & 3 & 5 & 7 \\
\hline 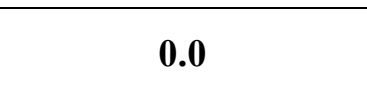 & $\begin{array}{l}\text { S } \\
\text { B }\end{array}$ & $\begin{array}{l}0.292 \\
1.161\end{array}$ & $\begin{array}{l}0.316 \\
1.188\end{array}$ & $\begin{array}{l}0.300 \\
1.165\end{array}$ & $\begin{array}{l}0.293 \\
1.162\end{array}$ & $\begin{array}{l}0.281 \\
1.160\end{array}$ & $\begin{array}{l}0.267 \\
1.173\end{array}$ \\
\hline 0.25 & $\begin{array}{l}\text { S } \\
\text { B }\end{array}$ & $\begin{array}{l}0.311 \\
1.040\end{array}$ & $\begin{array}{l}0.399 \\
0.892\end{array}$ & $\begin{array}{l}0.380 \\
0.888\end{array}$ & $\begin{array}{l}0.530 \\
0.865\end{array}$ & $\begin{array}{l}0.965 \\
0.729\end{array}$ & $\begin{array}{l}0.346 \\
0.130\end{array}$ \\
\hline 0.5 & $\begin{array}{l}\text { S } \\
\text { B }\end{array}$ & $\begin{array}{l}0.323 \\
0.035 \\
\end{array}$ & $\begin{array}{l}0.387 \\
0.011 \\
\end{array}$ & $\begin{array}{l}0.361 \\
0.016 \\
\end{array}$ & $\begin{array}{l}0.367 \\
0.020 \\
\end{array}$ & $\begin{array}{l}0.364 \\
0.025 \\
\end{array}$ & $\begin{array}{l}0.351 \\
0.029 \\
\end{array}$ \\
\hline 1.0 & $\begin{array}{l}\text { S } \\
\text { B }\end{array}$ & $\begin{array}{l}0.266 \\
0.077\end{array}$ & $\begin{array}{l}0.372 \\
0.041\end{array}$ & $\begin{array}{l}0.256 \\
0.041\end{array}$ & $\begin{array}{l}0.256 \\
0.024\end{array}$ & $\begin{array}{l}0.143 \\
0.023\end{array}$ & $\begin{array}{l}0.190 \\
0.021\end{array}$ \\
\hline
\end{tabular}

$\mathrm{S}=$ Sample $; \mathrm{B}=$ Blank

\section{Effect of the reagent amount}

The effect of different amounts of $0.1 \%$ 2,6-dihydroxybenzoic acid (DHBA) reagent on the maximum formation of the colored azo dye is investigated. The results are shown in Table (4). 
Table 4: Effect of the reagent amount on absorbance

\begin{tabular}{|c|c|c|c|c|c|}
\hline \multirow{2}{*}{$\begin{array}{c}\text { ml of 0.1\% } \\
\text { DHBA solution }\end{array}$} & \multicolumn{5}{|c|}{ Absorbance of different amounts of niclosamide $(\boldsymbol{\mu g})$ in10 $\mathbf{~ m l}$} \\
\cline { 2 - 6 } & $\mathbf{2 5}$ & $\mathbf{5 0}$ & $\mathbf{1 0 0}$ & $\mathbf{2 0 0}$ & $\mathbf{R}^{\mathbf{2}}$ \\
\hline $\mathbf{0 . 5}$ & 0.181 & 0.371 & 0.768 & 1.512 & 0.9998 \\
\hline $\mathbf{1 . 0}$ & 0.176 & 0.383 & 0.766 & 1.488 & 0.9994 \\
\hline $\mathbf{1 . 5}$ & 0.194 & 0.381 & 0.760 & 1.511 & 0.9990 \\
\hline $\mathbf{2 . 0}$ & 0.180 & 0.386 & 0.766 & 1.519 & 0.9999 \\
\hline $\mathbf{3 . 0}$ & 0.175 & 0.376 & 0.753 & 1.489 & 0.9993 \\
\hline
\end{tabular}

The results shown in Table 4 indicate that 1.5 and $2.0 \mathrm{ml}$ of DHBA solution give the higher sensitivity. $2 \mathrm{ml}$ has been selected for the subsequent experiments.

\section{Effect of bases}

The effect of different amounts of different bases on the color intensity of the azo dye has been tested. The results in Table (5) showed that the colored azo dye needs a strong basic medium and $0.6 \mathrm{ml}$ of $1 \mathrm{M} \mathrm{NaOH}$ solution gave the highest intensity for the azo dye, therefore it has been recommended in the subsequent experiments.

Table 5: Effect of quality and quantity of different bases

\begin{tabular}{|l|c|c|c|c|}
\hline \multirow{2}{*}{$\begin{array}{c}\text { Base used } \\
\mathbf{1 M} \\
\text { solution }\end{array}$} & \multicolumn{4}{|c|}{ Absorbance / ml of base added } \\
\cline { 2 - 5 } & $\mathbf{0 . 4}$ & $\mathbf{0 . 6}$ & $\mathbf{0 . 8}$ & $\mathbf{1 . 0}$ \\
\hline $\mathbf{N a O H}$ & 0.110 & 0.389 & 0.379 & 0.329 \\
\hline $\mathbf{K O H}$ & 0.087 & 0.373 & 0.386 & 0.383 \\
\hline $\mathbf{N a}_{\mathbf{2}} \mathbf{C O}_{3}$ & 0.137 & 0.177 & 0.177 & 0.263 \\
\hline $\mathbf{N a H C O}_{3}$ & 0.042 & 0.177 & 0.169 & 0.216 \\
\hline
\end{tabular}

\section{Effect of surfactants}

The effect of surfactants has been studied by the addition of $3 \mathrm{ml}$ of various types of surfactants [cetylpyridinium chloride (CPC), sodium dodecyl sulphate (SDS) and triton X100] to the medium of reaction with different orders of addition. The results indicate that there is no change in the intensity of the colored azo dye. Therefore, surfactants have been omitted in the subsequent experiments.

\section{Effect of time}

The effect of time on the development and stability of the colored azo dye for different amounts of RNIC is investigated under the optimum experimental condition. Complete color formation occurs immediately after the addition of the base, and the absorbance of the azo dye remains constant for at least $24 \mathrm{hrs}$ Table (6). 
Spectrophotometric Determination..........

Table 6: Effect of time on the absorbance of azo dye

\begin{tabular}{|c|c|c|c|}
\hline \multirow{2}{*}{ Time (min .) } & \multicolumn{3}{|c|}{ Absorbance/ $\boldsymbol{\mu g}$ of RNIC per $\mathbf{1 0} \mathbf{~ m I}$} \\
\cline { 2 - 4 } & $\mathbf{5 0} \boldsymbol{\mu} \mathbf{g}$ & $\mathbf{1 0 0} \boldsymbol{\mu g}$ & $\mathbf{2 5 0} \boldsymbol{\mu g}$ \\
\hline After addition & 0.386 & 0.756 & 1.846 \\
\hline $\mathbf{5}$ & 0.382 & 0.756 & 1.846 \\
\hline $\mathbf{1 0}$ & 0.380 & 0.759 & 1.846 \\
\hline $\mathbf{1 5}$ & 0.389 & 0.758 & 1.848 \\
\hline $\mathbf{2 0}$ & 0.387 & 0.758 & 1.849 \\
\hline $\mathbf{2 5}$ & 0.387 & 0.758 & 1.852 \\
\hline $\mathbf{3 0}$ & 0.387 & 0.757 & 1.854 \\
\hline $\mathbf{3 5}$ & 0.387 & 0.758 & 1.856 \\
\hline $\mathbf{4 0}$ & 0.387 & 0.758 & 1.858 \\
\hline $\mathbf{4 5}$ & 0.387 & 0.758 & 1.860 \\
\hline $\mathbf{5 0}$ & 0.387 & 0.758 & 1.862 \\
\hline $\mathbf{5 5}$ & 0.387 & 0.758 & 1.863 \\
\hline $\mathbf{6 0}(\mathbf{1 h r})$ & 0.390 & 0.759 & 1.864 \\
\hline $\mathbf{2}$ hrs. & 0.390 & 0.749 & 1.861 \\
\hline $\mathbf{3}$ hrs. & 0.390 & 0.748 & 1.864 \\
\hline $\mathbf{2 4}$ hrs. (1 day) & 0.374 & 0.733 & 1.819 \\
\hline
\end{tabular}

\section{Absorption spectra}

The absorption spectra of the yellow dye formed from reaction of the diazotized RNIC with DHBA in basic medium against its corresponding reagent blank show, a maximum absorption at $456 \mathrm{~nm}$. The reagent blank has practically negligible absorption at this wavelength (Fig. 2).

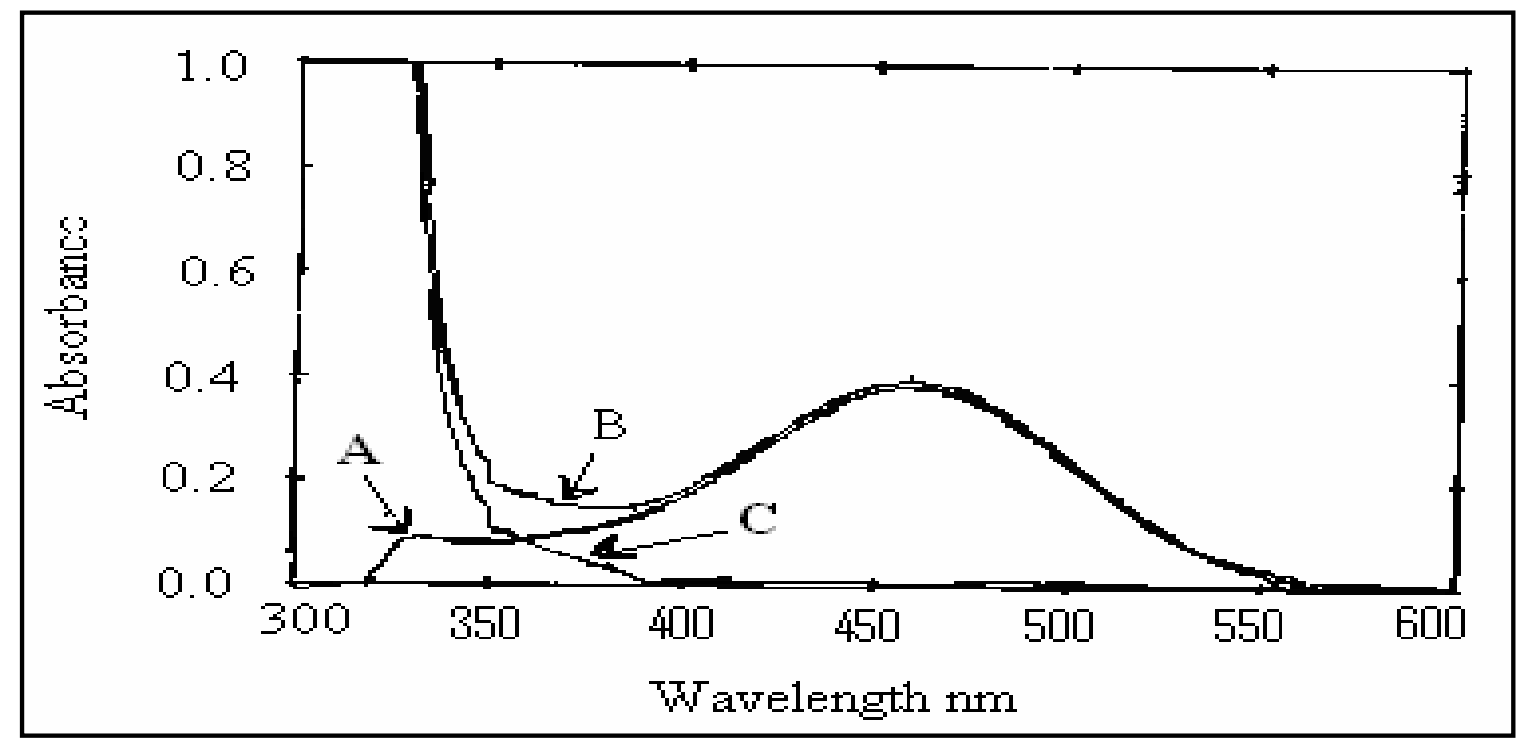

Fig. 2: Absorption spectra of $50 \mu \mathrm{g}$ of RNIC/ $10 \mathrm{ml}$ treated according to the optimum conditions and measured against (A) blank, (B) distilled water, and (c) blank measured against distilled water 


\section{Nature of the formed dye}

Jobs and mole-ratio methods (Hargis, 1988) have been used in the determination of the reaction ratio of RNIC to DHBA reagent. The obtained results showed that 1:1 RNIC to DHBA reagent ratio is obtained, and leads to the probability of the following structure

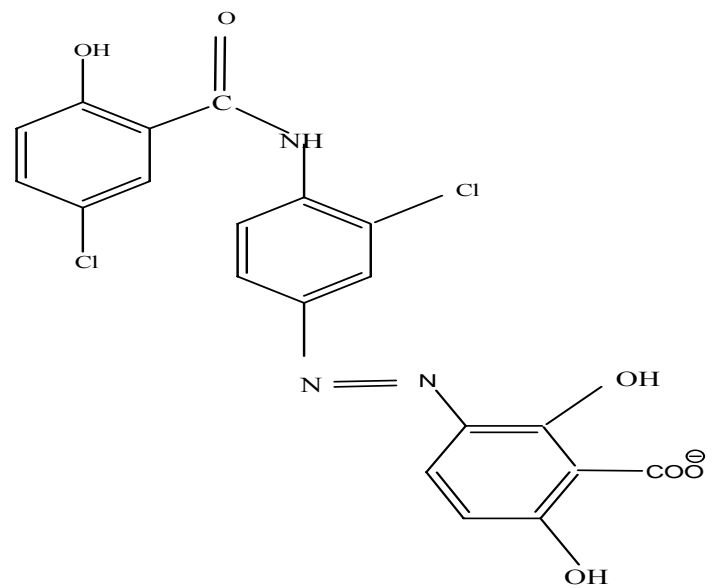

Yellow azo dye

Stability constant of formed azo dye

The stability constant of formed dye is calculated (Hargis, 1988). The results are shown in Table (7).

Table 7 : Stability constant of formed azo dye

\begin{tabular}{|c|c|c|c|c|}
\hline \multirow{2}{*}{$\begin{array}{c}\text { ml of } \mathrm{RNIC} \\
3.057 \times 10^{-4} \mathrm{M} \\
\text { solution }\end{array}$} & \multicolumn{3}{|c|}{ Absorbance } & \multirow[b]{2}{*}{$\mathrm{K},\left(\right.$ l. $\left.\mathrm{mol}^{-1}\right)$} \\
\hline & As & Am & $\boldsymbol{\alpha}$ & \\
\hline 0.5 & 0.384 & 0.396 & 0.0303 & $6.92 \times 10^{7}$ \\
\hline 1.0 & 0.728 & 0.763 & 0.0458 & $1.48 \times 10^{7}$ \\
\hline
\end{tabular}

The results in the above table indicate that the colored azo dye has a high stability.

\section{Interference of foreign species}

In order to realize the analytical application of the proposed method, the effects of foreign compounds have been studied by carrying out the determination of $50 \mu \mathrm{g}$ of niclosamide in the presence of each of the interferent using the recommended procedure and the results are given in Table (8).

Table 8: Effect of foreign compounds on determination of $50 \mu \mathrm{g}$ of niclosamide

\begin{tabular}{|l|c|c|c|c|}
\hline \multirow{2}{*}{ Interference } & \multicolumn{4}{|c|}{$\begin{array}{c}\text { Recovery (\%) of niclosamide / } \boldsymbol{\mu g} \text { of foreign } \\
\text { compound added }\end{array}$} \\
\cline { 2 - 5 } & $\mathbf{1 0 0}$ & $\mathbf{2 0 0}$ & $\mathbf{5 0 0}$ & $\mathbf{1 0 0 0}$ \\
\hline Starch & 101.2 & 98.7 & 100.7 & 98.2 \\
\hline Glucose & 101.2 & 100.9 & 100.7 & 102.2 \\
\hline Lactose & 101.7 & 98.5 & 99.0 & 99.5 \\
\hline Arabic Gum & 101.2 & 100.0 & 101.9 & 100.0 \\
\hline
\end{tabular}


From the above table, it can be observed that none of the foregin compounds can introduce significant interference.

\section{Application of the method}

The proposed method was successfully applied to the determination of niclosamide in its pharmaceutical preparations. The results which are shown in Table (9) indicate that a good recovery was obtained.

\section{Table 9: Analytical applications}

\begin{tabular}{|c|c|c|c|}
\hline Tablet & $\begin{array}{c}\text { Amount } \\
\text { taken, } \boldsymbol{\mu g}\end{array}$ & $\begin{array}{c}\text { Amount } \\
\text { measured, } \boldsymbol{\mu g}\end{array}$ & Recovery* ${ }^{*} \mathbf{o}$ \\
\hline \multirow{2}{*}{$\begin{array}{c}\text { Yomesan, 500 mg } \\
\text { Bayar - Germany }\end{array}$} & 25 & 24.8 & $99.2 \pm 0.00192$ \\
\cline { 2 - 4 } & 50 & 49.9 & $99.8 \pm 0.00240$ \\
\hline \multirow{2}{*}{$\begin{array}{c}\text { Yomesan, 500 mg } \\
\text { Bayar - Turkey }\end{array}$} & 250 & 249.2 & $99.6 \pm 0.00580$ \\
\cline { 2 - 4 } & 25 & 25.2 & $100.8 \pm 0.00230$ \\
\cline { 2 - 4 } & 50 & 49.3 & $98.6 \pm 0.00190$ \\
\hline
\end{tabular}

*Average of five determinations

The performance of the proposed method was assessed by the calculation of t-test compared with the standard method (British Pharmacopeia, 2000) (potentiometric method) for $95 \%$ confidence level with eight degrees of freedom. The results in Table 10 showed that the t-value was less than the critical value, indicating no significant difference between the proposed and standard method for niclosamide analysis.

Table 10: The results of t-test analysis

\begin{tabular}{|c|c|c|c|}
\hline \multirow[b]{2}{*}{ Tablet } & \multicolumn{2}{|c|}{ Recovery ${ }^{*}, \%$} & \multirow[b]{2}{*}{ t. exp } \\
\hline & $\begin{array}{l}\text { Present } \\
\text { method }\end{array}$ & $\begin{array}{c}\text { British } \\
\text { pharmacopeia } \\
\text { method }\end{array}$ & \\
\hline $\begin{array}{l}\text { Yomesan, } 500 \text { mg Bayar - } \\
\text { Germany }\end{array}$ & 99.8 & 99.5 & 0.502 \\
\hline $\begin{array}{l}\text { Yomesan, } 500 \text { mg Bayar - } \\
\text { Turkey }\end{array}$ & 98.6 & 98.9 & 0.709 \\
\hline
\end{tabular}

*Average of five determinations

\section{Comparison of the methods}

Table (11) shows the comparison between some of analytical variables obtained from the present method with that of the recent spectrophotometric method. 
Table 11: Comparison of methods

\begin{tabular}{|c|c|c|}
\hline Analytical parameter & Present method & Literature method * \\
\hline Reagent & 2,6-Dihydroxybenzoic acid & Phloroglucinol \\
\hline Medium of reaction & Aqueous & Aqueous \\
\hline pH & 12.0 & 13.0 \\
\hline Temperature $\left(\mathrm{C}^{\circ}\right)$ & Room temperature & Room temperature \\
\hline Development time (min.) & After dilution & After dilution \\
\hline$\lambda_{\max }(\mathrm{nm})$ & 456 & 434 \\
\hline Beer's law range (ppm) & $0.5-30$ & $1-26$ \\
\hline Molar absorbtivity $\left(1 . \mathrm{mol}^{-1} \cdot \mathrm{cm}^{-1}\right)$ & $2.36 \times 10^{4}$ & $1.40 \times 10^{4}$ \\
\hline Stability of the color (hrs.) & 24 & 3 \\
\hline Color of the dye & Yellow & Yellow \\
\hline Nature of the dye & $1: 1$ & $1: 1$ \\
\hline Application of the method & $\begin{array}{l}\text { Determination of niclosamide in } \\
\text { tablets }\end{array}$ & $\begin{array}{c}\text { Determination of } \\
\text { niclosamide in tablets }\end{array}$ \\
\hline
\end{tabular}

* (Al-Allaf, 2010)

The results in Table (11) indicate that the proposed method has the highest sensitivity and stability of the azo dye compared with the above literature method.

\section{CONCLUSION}

A simple, rapid and sensitive spectrophotometric method is described for the determination of niclosamide in pure and pharmaceuticals. The method is based on diazotization-coupling reaction between reduced form of niclosamide and 2,6dihydroxybenzoic acid in basic medium to produce a yellow azo dye which is very stable, water - soluble and has a maximum absorption at $456 \mathrm{~nm}$. The proposed method has been applied successfully to the assay of niclosamide in tablets.

\section{REFERENCES}

Abdel Fattah, S. (1997). Spectrophotometric determination of niclosamide using pbenzoquinone. Spectrosc. Lett., 30(5), 795-804.

Abreu, F.C.; Goulart, M.O.; Oliveira, A.M. (2002). Detection of the damage caused to DNA by niclosamide using an electrochemical DNA-biosensor. Biosen. Bioelectro., 17, 913-919.

Al-Allaf, I.T. (2010). Determination of niclosamide by spectrophotometric and high performance liquid chromatographic methods-Applications to pharmaceutical and veterinary preparations. M.Sc. Thesis, Department of Chemistry, College of Science, University of Mosul, $41 \mathrm{p}$.

Alemu, H.; Khoabane, N.M.; Tseki, P.F. (2003). Electrochemical oxidation of niclosamide at a glassy carbon electrode and its determination by voltammetry. Bull. Chem. Soc. Ethiopia, 17(1), 95-106.

Alfonso, R.G. (1995). "Remington: The Science and Practice of Pharmacy". 19th ed., Mack publishing Co., Easton, 1339 p. 
Algarra, M.; Campos, B.; Rodriguez, B.; Jose, E.; Sanchez, F. (2012). Niclosamide quantification in methyl- $\beta$ - cyclodextrin after derivatization to aminoniclosamide. J. Inclusion Phenomena Macroc. Chem., 72(1), 89-94.

"British Pharmacopia" (2000). CD- Rom. 3rd ed. System Simulation Ltd., the Stationary Office, London.

Budavari, S. (2001). "The Merk index". Merck and Co., N.J., 13th edn., 1167 p.

Caldow, M.; Sharman, M.; Kelly, M.; Day, J.; Hird, S.; Tarbin, J. (2009). Multiresidue determination of phenolic and salicylanilide anthelmintics and related compounds in bovine kidney by liquid chromatography - tandem mass spectrometry. J. Chromatogr., 1216(46), 8200-8205.

Cholifah, S.; Kartinasari, W.F.; Indrayanto, G. (2008). Simultaneous HPLC determination of levamisole hydrochloride and anhydrous niclosamide in veterinary powders and its validation. J. Liquid Chromatogr. Related Technol., 31(2), 281-291.

Churchill, F.C.; Ku, D.N. (1980). Extractive alkylation of 2', 5-Dichloro-4'nitrosalicylanilide (niclosamide) for gas-liquid chromatographic analysis. $J$. Chromatogr. 189(3), 375-388.

Daabees, H.G. (2000). Selective differential spectrophotometric methods for determination of niclosamide and drotaverine hydrochloride. Anal. Lett., 33(4), 639-656.

Fomovska, A.; Wood, R.D.; Mui, E.; Dubey, J.P. (2012). Salicylanilide inhibitors of Toxoplasma gondii. J. Medic. Chem., 55(19), 8375- 8391.

Ghalkani, M.; Shahrokhian, S. (2010). Application of carbon nanoparticle / chitosan modified electrode for the square-wave adsorptive anodic striping voltammetric determination of niclosamide. Electrochem. Comm., 12(1), 66-69.

Hargis, L.G. (1988). "Analytical Chemistry, Principles and Techniques". Prentice-Hall, International, London, pp. 424- 427.

John, S.J.; Geoffrey, B.P. (1980). Estimation of residues of the molluscicide, niclosamide, in bananas by gas-liquid chromatography of the heptafluorobutyryle derivative of the substituted aniline moiety. Pestic. Sci., 10(6), 531-539.

Lopatin, B.V.; Lopatina, N.B.; Bekhli, A.F. (1989). Spectrophotometric determination of fenasal (niclosamide) in tablets. Farmatsiya (Moscow), 38(3), 75-76.

Onur, F.; Tekin, N. (1994). Spectrophotometric determination of niclosamide and thiabendazole in tablets. Anal . Lett, 27 (12), 2291-2301.

Sastry, C.; Aruna, M.; Rama, A. (1988). Spectrophotometric determination of some antiamoebic and anthelmintic drugs with metol and chromium (VI). Talanta, 35(1), 23-26.

Schreier, T.M.; Dawson, V.K.; Choi, Y.; Spanjers, N.J.; Boogard, M.A. (2000). Determination of niclosamide residues in rain bow trout (Oncorhynchus mykiss) and channel catfish (Ictalurus punctatus) fillet tissue by high-performance liquid chromatography. J. Agric. Food Chem., 48, 2212-2215.

Sheng, L.Y.; Wei, W.; Tain, X.Y.; Jun, L.H. (2011). A strategy for emergency treatment of Schistosoma japonicum-infested water. Paras. Vectors, 4(1), 209209.

Wu, Y.Q.; Yang, T.S.; Li, X.; Wu, J.C. (2011). Novel derivatives of niclosamide synthesis: Its bioactivity and interaction with Schistosoma japonicum cercariae. Dyes and Pigments, 88(3), 326-332. 